\title{
PHILOLOGY
}

\section{THE RELATIONSHIP OF THE HISTORICAL PERSONALITY AND HERO OF THE ARTWORK OF CLASSICAL LITERATURE (ON EXAMPLE OF THE CREATIVITY OF BISOTY SAMARKANDY)}

\author{
Foziljon Shukurov, lecturer, \\ Department of Tajik Language and Literature, \\ Samarkand State University, Uzbekistan
}

DOI: https://doi.org/10.31435/rsglobal_ijitss/28022019/6370

\section{ARTICLE INFO}

Received 09 December 2018 Accepted 23 February 2019

Published 28 February 2019

\section{KEYWORDS}

Bisoty, artwork, historical personality, hero, Amir Teimur, sufism, music, chess, manuscripts, qasida, gazelle, qit'a, mukhammas, rubai, fard.

\begin{abstract}
This article is about works which is kept in the world`s libraries till today and their content, also poems` meaning of Bisoty Samarkandy who has lived and worked in the second half of fourteenth century and beginning of the fifteenth century. His poetry has attracted the attention of prominent literary scholars for many years. An in-depth study of the poet's work is one of the most important issues today.
\end{abstract}

Citation: Foziljon Shukurov. (2019) The Relationship of the Historical Personality and Hero of the Artwork of Classical Literature (on Example of the Creativity of Bisoty Samarkandy). International Journal of Innovative Technologies in Social Science. 2(14). doi: 10.31435/rsglobal_ijitss/28022019/6370

Copyright: (C) 2019 Foziljon Shukurov. This is an open-access article distributed under the terms of the Creative Commons Attribution License (CC BY). The use, distribution or reproduction in other forums is permitted, provided the original author(s) or licensor are credited and that the original publication in this journal is cited, in accordance with accepted academic practice. No use, distribution or reproduction is permitted which does not comply with these terms.

Introduction. After the conquest of Mongols, the cultural decadence in Maverannahr and Khorasan, especially its science and literature continued to exist until the appearance of Amir Timur (1336-1405) into political arena. When Amir Timur came into Central Asia, the forces of the Mongols were weakened here. The people began to take patriotic moves against foreign exploiters. Amir Timur, who had a high sense of patriotism, liberalism, and national pride, ended Mongols nearly 150-year tyranny, eliminating Maverannahr from the colonial occupation and establishing a strong central state.

Amir Timur founded absolute power in Maverannahr in 1370, and then built an emperor that included 27 states and Samarkand was its capital. At the same time, paralelly with 35-year-old selfimposed conquest Amir Timur rebuilded the Central Asian region, as it was the basis of the power of his state [1]. Samarkand became the center of statehood as in the pre-Mongol era (XI-XII centuries), and was built by the artists of the conquered lands. Traders came from Roma, Arab countries, Iran and India to Samarkand and then moved to Mongolia and China. Timur paid great importance to the construction of buildings. Especially focused on the development of surroundings of Samarkand city, and named them after famous cities - Shiraz, Baghdad, Damascus, Madrid and others [2]. In this situation Khorasan and Maverannahr was living literally. Of course, this process was weak during the Timur period, but the overall development process and the dialectic history of the development was not cut and disassociated, but in their relations, they developed their best practices and traditions. 
Amir Timur's efforts have also contributed to the development of science and literature. As academician Barthold W.W. also noted that "in addition to the Turkic language, he also knew Persian, he understood not only Islam, but also the Islamic science and culture, attracted the scientists and artists to Samarqand from all sides...» [3]

Amir Timur did a great job in two major things, first building of great constructions, second building structures, and irrigation canals, which show that he is an executive power. For example, famous masters built the palace of Aqsaray in Shahrisabz for Amir Timur in which all the poems in the walls were written in Persian language. But most of his political activities were connected with military trips, and he did not take much time to poetry. In scientific journals except the story of his conversation with Khoja Hafiz (1387), no other information has been provided. Also, Amir Timur has built a great tomb on the grave of Ahmad Yassevi, and the paper about its honoring was in Persian language too.

Amir Timur admired the culture and had good skills in chess, always talked with scholars, even once astonished famous historian Ibn Khaldun with his knowledge of ancient history. In addition to the science and culture, the poetry also continued in this period. Amir Timur has installed in his rings the words "Rosti-rasti" (Be true and you'll improve) in Persian language. Also, beggar Kabulshah, who was declared a khan (ruler) in 1366 and was later defeated, wrote poems too. One of the companions of Amir Timur, Amir Saifuddin Barlos also wrote poems in Persian and Turkic languages. It is evident that during Timur's period there was a bilingual tradition. After Amir Timur's period attention for science and literature became even more important. The poet Sakkoki wrote poems about prince Khalil Sulton, and afterwards about famous king and scholar- Ulughbek.

To slow down the movements of local khakims (rulers) of Maverannahr, Amir Timur had not opportunity to pay attention to science and literature environment. Amir Timur spent a lot of time to restore justice and stability in his state.

Historical and literary sources do not have much to mention about the Timur's attitude to literature or his residency's poets. However, this does not mean that Amir Timur has no interest in literature and poetry.

Materials and methods. Nowadays, beliefs about Amir Timur's dislike regarding literature and its followers will be rejected with qasidas written by famous poets, such as Bisoty Samarkandy, Khoja Ismati Bukharai, Khoja Abdulmalik Isami and others. In particular, we can cite as an example the book "Facts about the classification of poems", which was published in Beirut (Lebanon) in 2014 in Arabic, devoted to this period. The author of the book, scientist Shaikhoko Buzurg at-Tehrani, provides very useful information about copies of manuscripts of poets of various centuries, including announcing the presence of a manuscript of poems in the city of Beirut.

The manuscript is at number 4999, and is called the "Collection of poems of Isomii Samarkandy". The author cites that the name of the poet Abdulmalikhon and in the courtyard of Amir Timur was the head of the clergy. It says that "his name is Abdulmalikhon, in the courtyard of Amir Timur in Samarkand was the head of the clergy." He is a mentor of Bisoty Samarkandy. His poems are given under the pseudonym of Isomi under the number LT-5. The author also says that Isomi also wrote under the pseudonym "Futuhu-s-Salotin" ("Victory of the Kings") in Persian wrote Masnavi about the history of the Indian kings and finished it in 751 Hijri. About Isomi is also said in the "Book of knowledge of Persian literature" (Tehran, 1380), that it consists of 12 thousand couplets, was published in 1890 in the city of Calcutta. If we translate the number 751 Hijri into our era, then it turns out 1350, i.e. this work of Isomi was published during the reign of Amir Timur. Undoubtedly, after studying this work, one can clarify many abstract questions of this period. It becomes clear that at the beginning of Amir Timur's rule in Samarkand, literary life was in full swing and important works were composed.

In this period, Samarkand, as a scientific center, was awarded world literary fame. In this regard, the reason for the world fame of Samarkand is that famous scientists from various fields from the Middle East and Central Asia gathered here and conducted their activities. Mavlono Sirodiddin Bisoty Samarkandy is one of the famous poets of this period, who lived in the late XIV century and the beginning of the XV century and was one of the greatest poets of his time.

He became famous with his gazels and qasidas during Amir Timur's period. Especially during the reign of Amir Timur's grandson, the son of Shohruh Halil Sulton he became famous as a talented poet. He was a contemporary of such poets as Khayolii Bukhoroi, Burunduqi Bukhoroi, Rustami Khuriyoni, Tohiri Abevardi, Kamoli Khujandi, and wrote answers to some of their poems. For 
example, in "Tazkirat-ush-shuaro" ("Annals of Poets") Davlatshokh Samarkandy states: In one party of Khalil Sulton, the singer sang one couplet of ghazal of Bisoti:

The heart is like glass and your eyes like drunk and carry it in different directions. As if suddenly broken.

Khalil Sulton, who himself was also interested in poetry, was delighted with this couplet and ordered to find its author. As soon as they brought Bisoti, the prince praised him and gave him a thousand dinars. Davlatshoh after this story adds that from conscience Khalil Sulton, who was the owner of the treasury of Amir Timur, showed little nobility in relation to this beyt, i.e. in the opinion of the chronicler, the price of this bate is so high that, despite the large sum of money, a thousand dinars is insufficient. In fact, this beyt of Bisoti is a royal beyt, which was created in a pure and outstanding poetic image.

The poet's literary heritage is not very large in capacity; there is only one collection of poems left, copies of which are preserved in the form of a manuscript. Copies of the poet's collection according to Hasani Anushi, which leads to the "Book of Persian Literature Knowledge in Central Asia" are kept in St. Petersburg, London, Oxford, Tashkent cities. One copy is kept in Dushanbe city, in oriental manuscripts of the Academy of Sciences of the Republic of Tajikistan at number 160. A characteristic of this copy is given in the catalog of "Collection of Oriental Manuscripts of the Academy of Sciences of the Uzbek SSR": "Author is Mevlana Bisoty Samarkandy. The collection of poems was created during the beginning of the Timurid ruler, Khalil Mirzo. In the middle of the 19th century, the calligrapher Sharafiddin Husayn Bulgory was rewritten" [4].

On the lyrical poetry of the genres of the poet Hasani Anushi says: "... his collection of poems contains qasidah, ghazel, rubai, qit'a"[5]. Sadri Sadiyev connects the small volume of the poet's poetry collection with his early death. In addition to this, not only the pre-residence collection, but also the residence-period collection of poems has come down to our times in small quantities. The existing copy of the collection of the poet contains 116 gazelles and this small amount of his gazelles does not coincide with his recognized fame. Examples of some genres that Hasani Anushi mentioned, who identified based on a copy of London, Oxford, St. Petersburg, Tashkent, are not available in a copy of Dushanbe.

The copy of Bisoti's divan, which is available in electronic form, belongs to the Library of the National Assembly of Tehran, stored in the number 13003. The book is a collection of poetry, which is called "The Divan of eleven greatest poets" and as it is mentioned above, covers the poems collection of 11 poets [5].

As a result of the collection of poet's prints, today is available approximately 2013 verses (beyts), it is divided into the following lines:

1) Qasidas - 23, consisting of 642 beyts (verses);

2) Gazels - 113, consisting of 741 beyts;

3) Tarjeaats - 10, total 289 beyts;

4) Qit'aas - 38, total 284 beyts;

5) Rubai-3, up to 6 beyts;

6) Riddles - 2, totall1 beyts;

7) Fardiaats- 40, total 40 beyts.

Bisoti's qasidas also like the other poet's qasidas consists praisings of rulers and kings of that time, such as his master Khoja Abdulmalik, Mavlono Jaloluddin, Abu Saeed, Mir Muhammad, Amirzade Umar and others. During the study of Bisoti's qasidas, one of them which consists of 30 beyts, dedicated to Amir Timur, showing his skills in writing qasida. Qasida has been started with the following:

Oh, the glittering palace, which you like bright eyes,

You are the only one who takes the hearts

First of all, poet praises Amir Timur with words "Christ's companion ", "The Dignity Sun", "The bright star", "Sun of nine heaven", "The proud of sultans", "The king of justice", "Support of kindness", "King of lands", "Owner of the world" and so on, and then lists his attributes. In particular, in the 17th beyt of qasidah, the name of Amir Timur is also mentioned:

Victorious Amir Timur - he is the king who

Under the protection of his ring is all the power of Sanjar (ruler of Khorasan).

Then poet mentions Amir Timur's feats:

He is in a fight like the sun of the East and the West,

He is in a holiday like a sea full of pearls. 
For instance, he conquers Roman emperor and sets there his representative:

Your servant was sitting in the realm of Byzantium

He is shy (for himself considers base) to become known as Caesar.

The poet acknowledged his sword's victorious and triumphant feature and notes that he is sovereign and lord, and at the same time his fairness and contrition fulfills the heaven with diamonds. The poet in his praisings, emphasized humanism in ruling society, using justice and kindness over people and calls other rulers into justice by this way. Here, the poet's idea is based on the idea of a righteous king in the concept of Abu Nasr Farabi. That is, a poet's aim calling other rulers into justice by demonstrating their best features. As a matter of fact, he addresses his praises to Amir Timur and says that he set justice and favor in the country, so that "even the wolf is kind to the lamb" in the country:

From your justice is now everywhere

The wolf cares for the lamb as a mother.

From the poet's poetry it is clear that the goal is not to draw attention to the praise of the rulers, but to promote their righteousness as the example to others and by this way calling them to justice too.

After expression of this features in his praisings, Bisoti tells a major cause of writing of this qasidah. That is, he notes the building of palace made by Amir Timur (which is known in Samarkand) and its date has also been stated:

This palace which was built in your state

Now it is difficult to find words for his praise.

And this palace has been completed in 798, if it turns it to Christmas year 1496:

At seven hundred and ninety-eight, its building ended,

After hijrat (going from Mekkah to Medina) of prophet.

It is known that Bisoti was already well-known poet even before invitation to Khalil Sultan's residence and was also liked by Amir Timur.

Qasidah at number 13, which consists of 45 beyts (couplets), the first part, which covers the theme of beauty of nature, spring and Nawruz, the nightingale and flowers, consists of 10 couplets, and begins with the following beyt:

The colours (sign) of Nawruz become evident,

Today after dawn the early spring has come.

Then, starting from the 11th couplet, the poet begins to praise himself and praises the highest images and likeness:

He is the glorified, who, because of his majesty,

His charges consider it a shame to become a sultan.

The poet is not limited to praise and focuses on justice and humanity and says that "you have revived the good faith and philanthropy."

It's safe to say that the poet's goal of writing a qasidah is to promote the good and humane qualities of the rulers, in order to show them as examples for others. In general, in the works of Bisoti the word "justice" is given 5 times, "conscience" 4 times, "nobility" 31 times, "forgivability", "generosity" 2 times, which are considered the best qualities of rulers and kings.

So, we have information about Amir Timur states' poets and we know that they praised him in their poems. But this can not be a reality in the literary context of Amir Timur's residence. The above mentioned poets, just wrote qasidahs about triumphs and victories of Amir Timur.

Just Isomi had written many qasidahs about Amir Timur and was his residences' poet. Evidently, Isomi had a greater contact with Amir Timur and his residency. From these words, it can be concluded that in the second half of the 14th century in Samarkand the literary life was not only silent, but, on the contrary, all conditions were created for the activity of the creative intelligence and they fruitfully created interesting works. But there is no chronicle about the writers of Samarkand, as about the writers of Herat and therefore the names of many writers of Samarkand for us remain unknown. Not only does the existence of a separate chronicle, but also, as Sadri Sadiyev notes, in the existing chronicles writers of Herat and other places are mainly noted, and the names of Samarkand writers are given little. This side of the issue becomes problematic and difficulties arise in the study of their activities [6].

All this shows that during the era of the Amir Timur, the literature in his residence have not yet been formed. Poets still lived outside the residency of rulers, in the city of Samarkand [7].

It says that determining the existence of a literary environment during the rule of Amir Timur and his successor, Khalil Sulton, is an important issue. Exactly during this period Mevlana Bisoty has 
lived and this period showed a strong literature environment and had activity such famous poets as Isomii Samarkandy and Ismati Bukharai. Bisoti has owned the poetry skills from these masters and entered to Amir Timur's residency. From these words, it becomes clear that the determination of the existence of literary life during the rule of Amir Timur and his heirs, especially Khalil Sulton, is an important and urgent issue. It was during this period that Mevlana Bisoti lived and worked and gained worldwide fame. It was the presence of a powerful literary life that gave the opportunity for the work of such great poets as Isomii Samarkandy and Ismati Bukhoroi. Bisoti himself also studied the secrets of creativity and literature from these two poets and found access to the residence of the ruler.

Conclusions. Thus, it can be concluded that in the second half of the 14th century in Samarkand not only reigned a strong literary environment, but also progressed rapidly, evidence for this could be collections of poems by such famous poets as Khoja Abdulmalik Isomi and Bisoty Samarkandy. As a result of analysis and research, it becomes clear that they expressed their views on the events of that period. They not only wrote odes and laudatory poems, but also in their works as an example and sample, they praised Amir Timur and Khalil Sulton, and promoted their philanthropy and humane views and called the rulers to justice and humanity.

\section{REFERENCES}

1. Barthold W.W. Ulugbek I ego vremya // Sochineniya, Vol.4, II., Nauka, 1964, 139-140.

2. Barthold, W.W. Sochineniya, Vol 2, Part 2, 161.

3. Barthold, W.W. Sochineniya, Vol 2, Part 2, 160.

4. Barthold W. B. Halil-Sultan // Barthold V. B. Sochineniya. - M.: Nauka, 1964. - V. II, P. 2: Works on particular issues of Central Asia, 533-534.

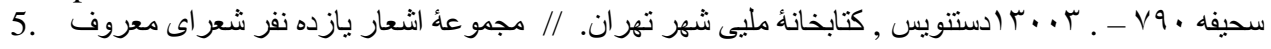

6. Sadri Sadiev. Samarkand literary center in the history path. -Tashkent: National Encyclopedia of Uzbekistan, 2012, 123-124.

7. Sadri Sadiev. Samarkand literary center in the history path. -Tashkent: National Encyclopedia of Uzbekistan, 2012, 139-156. 